\title{
TGF- $\beta$ inhibitor RepSox suppresses osteosarcoma via the JNK/Smad3 signaling pathway
}

\author{
DENGWEI HE ${ }^{1-3^{*}}$, JIAWEI GAO ${ }^{1,2^{*}}$, LIN ZHENG $^{1-3^{*}}$, SHIJIE LIU $^{1}$, LIN YE $^{1}$, HEHUAN LAI $^{1}$, BIN PAN $^{1}$, \\ WENZHENG PAN ${ }^{1}$, CHAO LOU $^{1}$, ZHENZHONG CHEN $^{1}$ and SHUNWU FAN ${ }^{2,3}$ \\ ${ }^{1}$ Department of Orthopedics, Affiliated Lishui Hospital of Zhejiang University, Lishui, Zhejiang 323000; \\ ${ }^{2}$ Department of Orthopedic Surgery, Sir Run Run Shaw Hospital, Zhejiang University School of Medicine, \\ Hangzhou, Zhejiang 310016; ${ }^{3}$ Key Laboratory of Musculoskeletal System Degeneration and \\ Regeneration Translational Research of Zhejiang Province, Hangzhou, Zhejiang 310016, P.R. China
}

Received May 9, 2021; Accepted July 29, 2021

DOI: $10.3892 / \mathrm{ijo} .2021 .5264$

\begin{abstract}
Osteosarcoma (OS) is the most common malignant bone tumor and the long-term survival rates remain unsatisfactory. Transforming growth factor- $\beta$ (TGF- $\beta$ ) has been revealed to play a crucial role in OS progression, and RepSox is an effective TGF- $\beta$ inhibitor. In the present study, the effect of RepSox on the proliferation of the OS cell lines (HOS and 143B) was detected. The results revealed that RepSox effectively inhibited the proliferation of OS cells by inducing S-phase arrest and apoptosis. Moreover, the inhibitory effect of RepSox on cell migration and invasion was confirmed by wound-healing and Transwell assays. Furthermore, western blotting revealed that the protein levels of molecules associated with the epithelial-mesenchymal transition (EMT) phenotype, including E-cadherin, N-cadherin, Vimentin, matrix metalloproteinase (MMP)-2 and MMP-9, were reduced by RepSox treatment. Concurrently, it was also revealed that the JNK and Smad3 signaling pathway was inhibited. Our in vivo findings using a xenograft model also revealed that RepSox markedly inhibited the growth of tumors. In general, our data demonstrated that RepSox suppressed OS proliferation, EMT and promoted apoptosis by inhibiting the JNK/Smad3 signaling pathway. Thus, RepSox may be a potential anti-OS drug.
\end{abstract}

\section{Introduction}

Osteosarcoma (OS) is one of the most common malignant bone cancers, originating from mesenchymal tissue, with

Correspondence to: Dr Shunwu Fan, Department of Orthopedic Surgery, Sir Run Run Shaw Hospital, Zhejiang University School of Medicine, 3 East Qingchun Road, Hangzhou, Zhejiang 310016, P.R. China

E-mail: shunwu_fan@zju.edu.cn

*Contributed equally

Key words: transforming growth factor- $\beta$, RepSox, osteosarcoma, $\mathrm{JNK} / \mathrm{Smad} 3$, therapeutic two high-incidence groups in adolescent and elderly individuals. The annual incidence rate of OS is approximately 4.4/1 million (1). In the early 1970 s, with the advent of neoadjuvant chemotherapy combined with surgical resection, the 5-year survival rate of OS was increased from 20 to $70 \%$ (2-4). Unfortunately, the survival rate of OS has not improved in the past 30 years. Therefore, it is extremely urgent to study the pathogenesis of OS and explore new therapeutic targets.

Transforming growth factor- $\beta$ (TGF- $\beta$ ) participates in the regulation of a variety of cellular biological processes through its TGF- $\beta$ type I and type II receptors, including cell proliferation, differentiation, apoptosis, adhesion and migration, and acts on the downstream Smad pathway (classical) and non-Smad pathway (nonclassical) $(5,6)$. Dysfunction of TGF- $\beta$ leads to serious consequences, even tumorigenesis (7). Accumulating evidence has revealed that there is a close relationship between elevated TGF- $\beta$ expression and the progression of tumors, such as lung, colorectal, prostate and gastric cancer. Additionally, the high expression of TGF- $\beta$ in colorectal, prostate and breast cancer is positively correlated with tumor metastasis (8-10). Moreover, the serum TGF- $\beta$ concentration in patients with OS lung metastasis is higher than that in patients without pulmonary metastasis $(11,12)$. Therefore, it was hypothesized that the inhibition of the TGF- $\beta$ signaling pathway may play a protective role in the occurrence and development of OS.

RepSox is a small molecule compound that acts as an inhibitor of TGF- $\beta$ I receptor kinase $(13,14)$. A recent study indicated that RepSox could inhibit osteoclast formation and bone resorption through the Smad3 and JNK/AP-1 pathway (15). Moreover, it has been reported that RepSox can induce mouse fibroblasts to reprogram into cardiomyocytes (16), improve the antitumor effects of antigen-presenting and immune-effector cells that are impaired in acute myeloid leukemia (17), and inhibit skin fibrosis (18). To date, no studies have been performed reporting the role of RepSox on tumors and its underlying mechanism. Therefore, the effects caused by RepSox on bone tumors remain unknown.

In the present study, the effects of RepSox on the proliferation, cell cycle, apoptosis and metastasis of OS cell lines 
in vitro and its effect on a tumor xenograft mouse model was therefore analyzed.

\section{Materials and methods}

Media and reagents. RepSox and dimethyl sulfoxide (DMSO) were purchased from Sigma-Aldrich; Merck KGaA. Dulbecco's modified Eagle's medium (DMEM), fetal bovine serum (FBS) and penicillin-streptomycin were purchased from Gibco; Thermo Fisher Scientific, Inc. Cell Counting Kit-8 (CCK-8) reagent was obtained from Dojindo Molecular Technologies, Inc. Primary antibodies against JNK2 (product no. 9258S), phosphorylated (p)-JNK (product no. 4668S), ERK1/2 (product no. 5013S), p-ERK1/2 (product no. 4370S), p38 (product no. 8690 S), p-p38 (product no. 4511S), Smad3 (product no. 9513S), p-Smad3 (product no. 9520S) and GAPDH (product no. 3683S) were purchased from Cell Signaling Technology, Inc. Primary antibodies against matrix metalloproteinase (MMP)-2 (cat. no. 10373-2-AP) and MMP-9 (cat. no. 10375-2-AP) were purchased from ProteinTech Group, Inc. Primary antibodies against Bax (product no. 5023S), Bcl-2 (product no. 3498S), E-cadherin (product no. 3195S), N-cadherin (product no. 4061S) and vimentin (product no. 5741S) were purchased from Cell Signaling Technology, Inc.

Cell culture. HOS and 143B cells were purchased from the Chinese Academy of Sciences (Shanghai, China) and maintained in DMEM containing $10 \%$ FBS and $1 \%$ penicillin/streptomycin. Both cell lines were routinely stored at $37^{\circ} \mathrm{C}$ in a humidified incubator with $5 \% \mathrm{CO}_{2}$.

Cell proliferation assays. To determine the effective inhibitory concentration of RepSox on cell viability, HOS and 143B cells were seeded at $3 \times 10^{3}$ cells/well into 96-well plates and incubated at $37^{\circ} \mathrm{C}$ overnight. Cells were then treated with increasing concentrations of RepSox ranging from 0 to $200 \mu \mathrm{M}$ for 24 , 48 or $96 \mathrm{~h}$. The DMSO alone group was used as the negative control group. Subsequently, $10 \mu \mathrm{l}$ of Cell Counting Kit- 8 (CCK-8) buffer was added to each well containing $100 \mu$ l culture medium. The plate was incubated for another $2 \mathrm{~h}$ at $37^{\circ} \mathrm{C}$, and the absorbance at a wavelength of $450 \mathrm{~nm}$ was measured using an ELX800 absorbance microplate reader (BioTek Instruments, Inc.). Cell viability was calculated as follows: Cell viability $(\%)=[\mathrm{A}$ (RepSox)-A (blank)]/[A (Control)-A (blank)] x100\%; where A (RepSox) is the absorbance of wells with cells, CCK-8 solution and RepSox; A (blank) is the absorbance of wells with medium and CCK-8 solution but no cells; and A (Control) is the absorbance of wells with cells and CCK-8 solution but without RepSox. The cell growth rate was calculated by GraphPad Prism software (version 7.0; GraphPad Software, Inc.). Firstly, the drug concentration was converted into a logarithmic form as the $\mathrm{x}$-axis, and then data fitting was performed through nonlinear regression, and finally the $\mathrm{IC}_{50}$ value was obtained. For cell colony formation, HOS and 143B cells were plated in 6-well plates at a cell density of 1,000 cells/well and then treated with different doses of RepSox $(0,50,100$ and $200 \mu \mathrm{M})$ supplemented with DMEM with $10 \%$ FBS for 2 weeks. The colonies were visualized under a light microscope (Carl Zeiss AG) and images were captured after staining with $0.5 \%$ crystal violet solution for $20 \mathrm{~min}$ at room temperature. Colonies containing at least 50 cells were recorded for statistical analysis.

Flow cytometry. HOS and 143B cells $\left(5 \times 10^{4}\right.$ cells/well) were seeded in 6-well plates and exposed to RepSox at concentrations of $0,50,100$ and $200 \mu \mathrm{M}$ for $48 \mathrm{~h}$. An equal volume of DMSO was added to the negative control group. After $48 \mathrm{~h}$, the cells were harvested with trypsin and washed twice with chilled PBS. Then, single-cell suspensions treated with different concentrations of RepSox were fixed overnight at $4^{\circ} \mathrm{C}$ with prechilled $70 \%$ ethanol. The following day, the cells were incubated with $500 \mu \mathrm{l} \mathrm{PI} / \mathrm{R}$ Nase solution for $30 \mathrm{~min}$ in the dark at room temperature. Subsequently, a flow cytometer (BD FACSCanto II; BD Biosciences) was used to analyze the samples and assess the cell cycle results. Similarly, to investigate the effect of RepSox on the viability of OS cells, the cells incubated with 0, 50, 100 and $200 \mu \mathrm{M}$ RepSox were collected and washed with PBS. The cells were then stained with an Annexin V-fluorescein isothiocyanate (FITC)-PI cell apoptosis kit (cat. no. 556547; BD Biosciences) at room temperature for $15 \mathrm{~min}$, according to the manufacturer's protocol, and apoptosis rates were analyzed by flow cytometry. Data were analyzed using FlowJo software 7.6.5 (FlowJo LLC).

Soft agar colony formation assay. The OS cells were trypsinized and harvested, and $5 \times 10^{3}$ cells were mixed with a $0.3 \%$ agar solution in DMEM containing 10\% FBS. In addition, different doses of RepSox were added at concentrations of 0 , 50,100 and $200 \mu \mathrm{M}$. The suspensions were layered on top of a solidified $0.5 \%$ agarose layer in 6 -well plates. The plates were then stored at $37^{\circ} \mathrm{C}$ for 2 weeks, and representative images of the cell colonies were obtained under a light microscope. Colonies containing at least 50 cells were recorded for statistical analysis.

Wound-healing assay. In brief, the cells ( $1 \times 10^{5}$ per well) were cultured in 6-well plates with DMEM containing 10\% FBS overnight at $37^{\circ} \mathrm{C}$ until a confluence of $90 \%$ was reached. Then the cells were starved in serum-free medium for $24 \mathrm{~h}$. A sterile pipette tip was used to scratch the cell layer to produce an artificial wound line. The cells were then rinsed with PBS to clear the detached cells. The drug was diluted to the specified concentration $(0,5,10$ and $20 \mu \mathrm{M})$ in serum-free DMEM medium and the cells were treated at $37^{\circ} \mathrm{C}$ for $24 \mathrm{~h}$. An equal volume of DMSO was added to the negative control group. The cells were monitored and images were captured under a light microscope at 0 and $24 \mathrm{~h}$.

Cell invasion and migration assays. A total of 24-well Transwell chambers with an $8-\mu \mathrm{m}$ pore size polycarbonate membrane (Corning, Inc.) were used to evaluate the cell migration and invasion abilities. For the invasion assay, the Matrigel was pre-coated on the membranes of the upper chamber at $37^{\circ} \mathrm{C}$ for $1 \mathrm{~h}$ according to the manufacturer's protocol (BD Biosciences). For the migration and invasion assays, $100 \mu \mathrm{l}$ suspension of cancer cells $\left(5 \times 10^{4}\right)$ was added to the upper compartment with serum-free DMEM, and the lower compartment was filled with $600 \mu \mathrm{l}$ of DMEM supplemented with $10 \%$ FBS. A preset concentration of RepSox $(0,5,10$ and $20 \mu \mathrm{M})$, which was used as a source of chemoattractant, was concurrently added to the 
lower compartment of the chamber. After culturing at $37^{\circ} \mathrm{C}$ for $24 \mathrm{~h}$, the non-invading/non-migrated cells were wiped off with a cotton swab. The invading/migrated cells that had invaded/migrated to the lower side were fixed at room temperature with $4 \%$ paraformaldehyde for $20 \mathrm{~min}$ and stained with $0.5 \%$ crystal violet solution at room temperature for $30 \mathrm{~min}$. Finally, images of the invading/migrated cells were captured and cells were counted under an inverted light microscope.

Western blot analysis. After treatment with the indicated concentrations of RepSox, the cells were rinsed with precooled PBS and collected with a cell scraper. Total protein was obtained by lysing cells with RIPA lysis buffer (Dalian Meilun Biology Technology Co., Ltd.) containing phosphatase inhibitor and protease inhibitor for $20 \mathrm{~min}$ at $4^{\circ} \mathrm{C}$, and centrifugation $\left(12,000 \mathrm{x}\right.$ g for $15 \mathrm{~min}$ at $\left.4^{\circ} \mathrm{C}\right)$. Protein concentration determination was measured by BCA kit. Equal amounts (10 $\mu \mathrm{g} / \mathrm{lane})$ of protein samples were separated by $8 \%$ or $10 \%$ sodium dodecyl sulfate-polyacrylamide (SDS-PAGE) gels by electrophoresis and transferred to a polyvinylidene fluoride (PVDF) membrane (EMD Millipore). Then, the membrane was blocked with $5 \%$ skimmed milk or $5 \%$ bovine serum albumin (BSA) (Sigma-Aldrich; Merck KGaA) for $1 \mathrm{~h}$ at room temperature and incubated overnight at $4^{\circ} \mathrm{C}$ with the appropriate primary antibodies (dilution 1:1,000) followed by horseradish peroxidase (HRP)-conjugated secondary antibodies (dilution 1:3,000; cat. nos. FDM007 and FDR007; Hangzhou Fude Biological Technology Co., Ltd.) for $1 \mathrm{~h}$ at room temperature. Subsequently, an enhanced chemiluminescence kit (FD8030; Hangzhou Fude Biological Technology Co., Ltd.) was used for the analysis of the protein interactions after exposure in an imaging system, and the protein band images were quantified with ImageJ (version 1.48; National Institutes of Health).

$R N A$ extraction and reverse transcription-quantitative $(R T-q)$ $P C R$. The MMP-2 and MMP-9 gene expression levels in HOS and 143B cells were detected by qPCR. Total RNA was isolated from OS cell lines and tumor tissues by TRIzol ${ }^{\circledR}$ reagent (Invitrogen; Thermo Fisher Scientific, Inc.) after treatment with different doses of RepSox. cDNA templates were synthesized by reverse transcription using a PrimeScript ${ }^{\mathrm{TM}}$ RT reagent Kit (Takara Bio, Inc.) according to the manufacturer's instructions. Then, the cDNAs were quantified by a LightCycler ${ }^{\circledR}$ 480II PCR instrument (Roche Diagnostics) to determine the expression of related genes by using UltraSYBR Mixture (Applied Biosystems; Thermo Fisher Scientific, Inc.). The thermocycling conditions were as follows: $95^{\circ} \mathrm{C}$ for $10 \mathrm{~min}, 40$ cycles at $95^{\circ} \mathrm{C}$ for $15 \mathrm{sec}$, and $60^{\circ} \mathrm{C}$ for $1 \mathrm{~min}$. The sequences of the primers used were as follows: GAPDH forward, 5'-GGAAGGTGAAGGTCGGAG TCA-3' and reverse, 5'-GTCATTGATGGCAACAATATCC ACT-3'; MMP-9 forward, 5'-TGTACCGCTATGGTTACAC TCG-3' and reverse, 5'-GGCAGGGACAGTTGCTTCT-3'; MMP-2 forward, 5'-TTGATGGCATCGCTCAGATC-3' and reverse, 5'-TTGTCACGTGGCGTCACAGT-3'; TGF- $\beta$ forward, 5'-GGCCAGATCCTGTCCAAGC-3' and reverse, 5'-GTGGGT TTCCACCATTAGCAC-3'; cyclin E1 forward, 5'-AAGGAGC GGGACACCATGA-3' and reverse, 5'-ACGGTCACGTTTG CCTTCC-3'; cyclin-dependent kinase (CDK)2 forward, 5'-CCAGGAGTTACTTCTATGCCTGA-3' and reverse, 5'-TTC ATCCAGGGGAGGTACAAC-3'; cyclin A2 forward, 5'-CGC
TGGCGGTACTGAAGTC-3' and reverse, 5'-GAGGAACGG TGACATGCTCAT-3'; p21 forward, 5'-TGTCCGTCAGAAC CCATGC-3' and reverse, 5'-AAAGTCGAAGTTCCATCG CTC-3'. Relative mRNA expression was calculated as $2^{-\Delta \Delta C q}$ (19).

Xenograft tumor model. All animal experiments were approved (approval no. 20190712) by the Animal Care Ethics Committee of Sir Run Run Shaw Hospital (Hangzhou, China). All animal studies were conducted in accordance with the National Institutes of Health Guide for the Care and Use of Laboratory Animals. Animals were kept under standard laboratory conditions (temperature $22 \pm 2^{\circ} \mathrm{C}$; relative humidity $50 \pm 10 \%$; 12-h light/dark cycle) with access to food and water ad libitum. A xenograft model of 6 -week-old male nude mice with an average weight of $18.05 \mathrm{~g}$ was established by subcutaneous injection of 143B cells on one side of the back. In our in vivo experiments, $3 \times 10^{6} 143 \mathrm{~B}$ cells were made into a suspension with sterile PBS and inoculated subcutaneously into one side of the 6-week-old male nude mice (Shanghai Institutes for Biological Sciences Shanghai Laboratory Animal Center) to establish tumor formation models. One week later, when tumors grew to be visible to the naked eye, a total of 15 nude mice were randomly assigned to three groups. RepSox treatment was initiated until the tumor volume reached approximately $50 \mathrm{~mm}^{3}$. Treatment ( 5 and $20 \mathrm{mg} / \mathrm{kg}$ ) groups were administered RepSox at 5 and $20 \mathrm{mg} / \mathrm{kg}$ every other day, respectively, while the control group was injected with DMSO. The tumor volume (V) was monitored and calculated every week based on the formula $\mathrm{V}$ (volume) $=\pi \mathrm{x} L$ (length) $\mathrm{x} \mathrm{W}(\text { width })^{2} / 6$. After continuous observation for 3 weeks, all the mice were euthanized, and the tumors were resected and weighed for further study. Animal euthanasia was performed by cervical dislocation under $2 \%$ isoflurane anesthesia.

TUNEL assay. The TUNEL assay was performed according to the manufacturer's instructions of a One-Step TUNEL Apoptosis Assay kit (Beyotime Institute of Biotechnology), which was used to analyze the level of apoptosis in cell and tissue specimens. The pretreated cells were seeded in a 24-well plate at a density of $1 \times 10^{4}$ cells/well, and then fixed with $4 \%$ formaldehyde for $30 \mathrm{~min}$, blocked with $5 \%$ bovine serum albumin (BSA) and incubated with $0.1 \%$ Triton X-100 at room temperature for $5 \mathrm{~min}$. The slides were washed with PBS, and $50 \mu \mathrm{l}$ of TUNEL reaction mixture was added to the cells, followed by incubation at $37^{\circ} \mathrm{C}$ in the dark for $1 \mathrm{~h}$. Nuclei were counterstained with 4,6-diamidino-2-phenylindole (DAPI) at $37^{\circ} \mathrm{C}$ for $10 \mathrm{~min}$. Images of the sections were captured under a fluorescence microscope, and the positive cells were counted. The nucleus stained with DAPI was blue. The cells exhibiting green fluorescence were considered apoptotic cells. Analysis of TUNEL-positive cells was carried out on five fields of view on each of the four slides in three independent experiments.

Histological and immunohistochemical analyses. Tissue blocks from excised tumors were fixed with $10 \%$ formalin for $48 \mathrm{~h}$ at room temperature and embedded in paraffin. Then, $4-\mu \mathrm{m}$ sections were stained with hematoxylin for $5 \mathrm{~min}$ and eosin for $2 \mathrm{~min}$ at room temperature for histological examinations and morphometric analysis. For immunohistochemical staining, the paraffin sections were first deparaffinized, and 
then the sections were heated in citrate buffer for antigen retrieval. Sections were then incubated with $3 \%$ hydrogen peroxide in phosphate-buffered saline (PBS) at $37^{\circ} \mathrm{C}$ for 5 min, and blocked with $3 \%$ bovine serum albumin (BSA) in PBS at $37^{\circ} \mathrm{C}$ for $1 \mathrm{~h}$. Slides were incubated overnight at $4^{\circ} \mathrm{C}$ with primary antibodies against Bax (dilution 1:100), Bcl-2 (dilution 1:400; product no. 15071; Cell Signaling Technology, Inc.), E-cadherin (dilution 1:400), N-cadherin (dilution 1:125; product no. 13116; Cell Signaling Technology, Inc.), vimentin (dilution 1:100), MMP-2 (dilution 1:100), MMP-9 (dilution 1:100) and Ki67 (dilution 1:500; product no. 9449; Cell Signaling Technology, Inc.), followed by incubation with biotinylated secondary antibodies (dilution 1:50; product nos. 8114 and 8125; Cell Signaling Technology, Inc.) for $1 \mathrm{~h}$ at room temperature.

Statistical analysis. All the data presented in this study were obtained from at least three independent experiments and were analyzed using GraphPad Prism software (version 7.0; GraphPad Software, Inc.). Values are presented as the mean \pm SD of 3 independent experiments. Statistical analyses were performed using unpaired Student's t-test or one-way analysis of variance (ANOVA) followed by Tukey's post hoc analysis. $\mathrm{P}<0.05$ was considered to indicate a statistically significant difference.

\section{Results}

RepSox inhibits cell proliferation and colony formation and induces $S$-phase arrest. The chemical structure of RepSox is revealed in Fig. 1A. Firstly, to evaluate the inhibitory effect of RepSox on the viability of human OS cells, RepSox with concentration gradients ranging from 0 to $200 \mu \mathrm{M}$ was used to treat HOS and 143B cells, and a CCK- 8 assay was used to detect cell viability at 24, 48 and 96 h (Fig. 1B). As revealed in Fig. 1B, RepSox significantly inhibited the proliferation of HOS and 143B cells in a time- and concentration-dependent manner. In the following colony formation assays, it was also revealed that the colony size and number of HOS and 143B cells treated with RepSox were significantly inhibited. The results revealed a concentration dependence with statistically significant differences in the number and size of colonies (Fig. 1C and D). In addition, a soft agar colony formation assay was further performed, which is a three-dimensional environment that simulates the growth of OS in vivo. It was revealed that as the drug concentration increased, the inhibitory effect on the number and size of colonies tended to become markedly more pronounced (Fig. 1E and F).

To investigate whether the inhibitory effect of RepSox on OS proliferation is related to the cell cycle, the cell cycle distribution of HOS and 143B cells induced by RepSox was further verified using PI/RNase staining. As demonstrated in Fig. $1 \mathrm{G}$ and H, RepSox led to the reduction of the number of cells in the G0/G1 phase and a corresponding accumulation in the S phase in both HOS and 143B cells. Based on the aforementioned results, it could be concluded that RepSox can inhibit the proliferation of OS cells by inducing S-phase arrest. To further elucidate the mechanism of the S-phase arrest of OS cells induced by RepSox, the mRNA levels of cycle-related genes were examined. As revealed in Fig. S1, the mRNA levels of cyclin E1 and p21 were upregulated after RepSox treatment, while the mRNA levels of CDK2 and cyclin A2 were decreased. The aforementioned results indicated that RepSox could inhibit cell proliferation and induce S-phase arrest of OS cells by upregulating the expression of cyclin E1 and p21 mRNA, and downregulating the expression of CDK2 and cyclin A2 mRNA.

RepSox promotes OS cell apoptosis. To clarify whether apoptosis is responsible for the inhibition of proliferation in OS cells following RepSox treatment, flow cytometry and TUNEL staining were used to detect the apoptosis levels. To quantify apoptosis, FITC-Annexin V/PI staining was performed to examine the proapoptotic effect of RepSox. In both HOS and 143B cell lines, the proportion of apoptosis in the treatment group exposed to RepSox for $48 \mathrm{~h}$ was significantly higher than that in the control group, regardless of early or late apoptotic status, and the apoptotic rate in early apoptotic cells was affected in a dose-dependent manner (Fig. 2A and B). TUNEL staining assays were used to detect the effect of RepSox on DNA damage in apoptotic OS cells. Fig. 2C and D revealed that RepSox-induced TUNEL-positive cells could be clearly observed, whereas the proportion of TUNEL-positive cells was negligible in the control group. Furthermore, western blotting was used to detect apoptosis-related proteins, and the results revealed that the expression of pro-apoptotic Bax protein increased with increasing drug concentration, while the expression of anti-apoptotic $\mathrm{Bcl}-2$ protein was decreased (Fig. 2E and F). Collectively, these results indicated that RepSox induced typical apoptosis in human OS cells.

RepSox inhibits migration in OS cells. To further evaluate the effect of RepSox on OS cell migratory behavior, a wound-healing assay was performed. Here, the drug concentration was reduced below the toxicity level (from 50-200 $\mu \mathrm{M}$ to 5-20 $\mu \mathrm{M}$ ) in order to rule out the bias caused by cell proliferation inhibition. The migration distance was obviously shorter in cells subjected to RepSox treatment for $24 \mathrm{~h}$ than in untreated cells. The effect of inhibition was dose-dependent (Fig. 3A and B). Concurrently, longitudinal migration experiments were carried out by using a Transwell chamber. Representative images of cell migration and invasion are presented in Fig. 3C, and it was revealed that the number of transmembrane cells in the RepSox treatment group was significantly less than that in the control group. Furthermore, the number of transmembrane cells decreased with higher concentrations of RepSox (Fig. 3D). The Transwell chamber was then coated with a layer of Matrigel to detect the invasion ability of OS cells, and the obtained results were consistent with the migration experiment (Fig. 3C and D). In addition, the results of RT-q PCR (Fig. 3E) and western blotting (Fig. 3F) revealed that RepSox significantly inhibited the expression of MMP-2 and MMP-9 in HOS and 143B cells. Next, the expression of EMT-related proteins was further examined and it was revealed that in cells pretreated with RepSox the protein levels of mesenchymal markers ( $\mathrm{N}$-cadherin and vimentin) were significantly downregulated, but the levels of the epithelial cell marker E-cadherin were significantly upregulated (Fig. 3G and $\mathrm{H}$ ). All these results indicated that RepSox could inhibit migration in OS cells. 
A<smiles>Cc1cccc(-c2n[nH]cc2-c2ccc3ncccc3n2)n1</smiles>

C

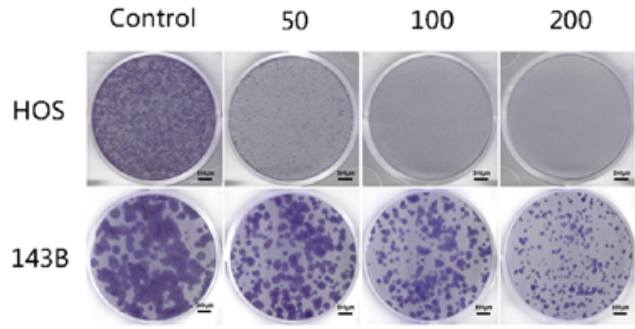

E

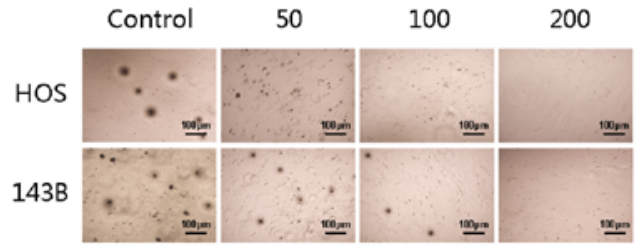

B
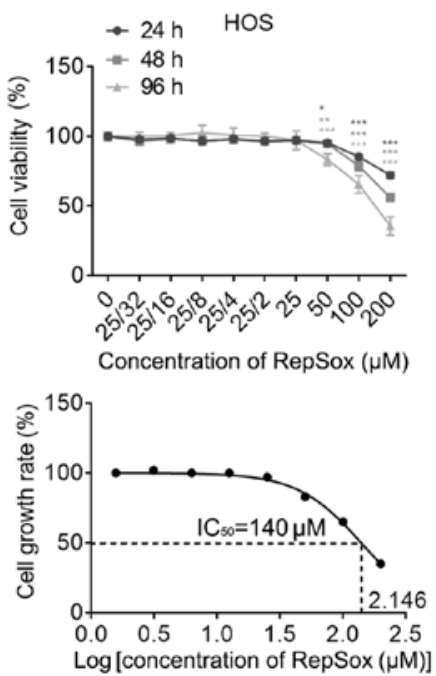
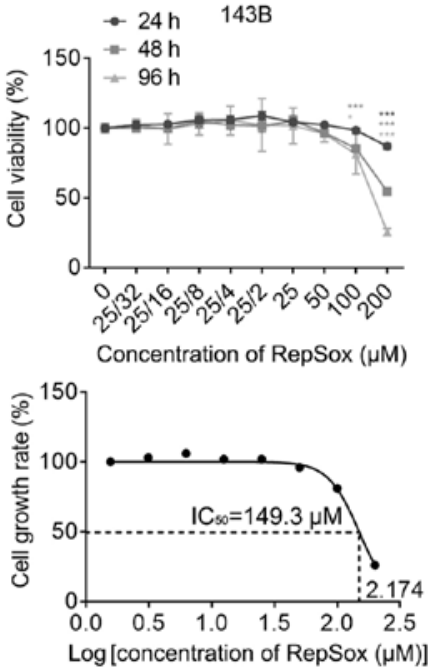

D

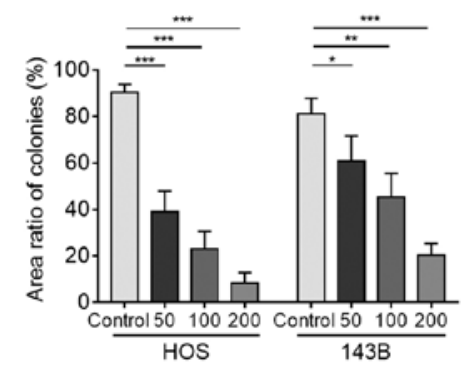

F
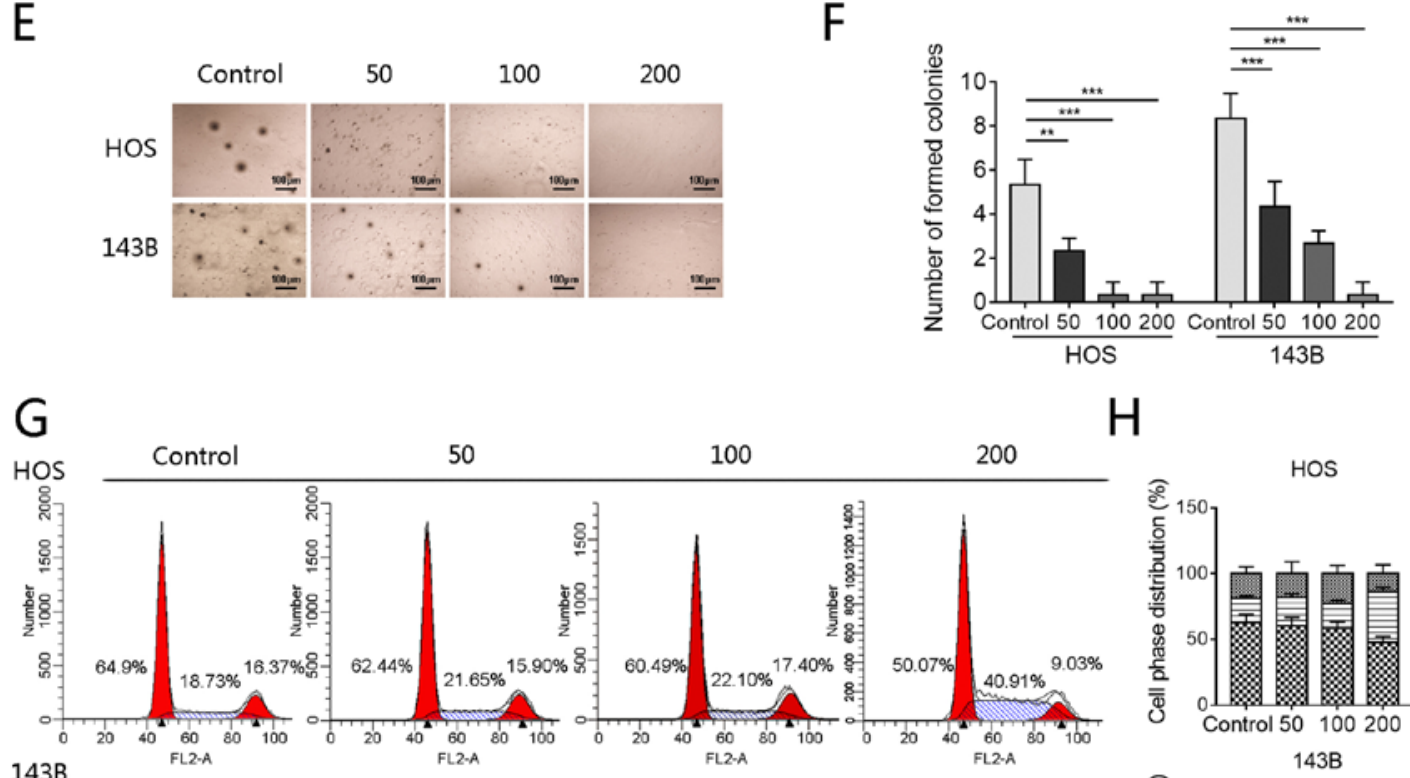

$\mathrm{H}$

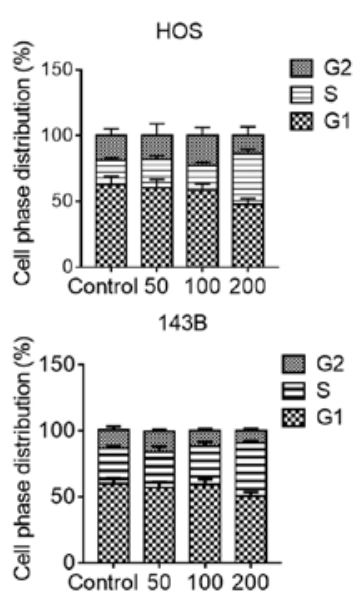

Figure 1. RepSox inhibits cell proliferation and colony formation and induces S-phase arrest. (A) Chemical structure of RepSox. (B) HOS and 143B cells were exposed to different concentrations of RepSox, and Cell Counting Kit- 8 assays were used to assess cell viability at 24,48 and $96 \mathrm{~h}$. The calculated IC 50 values of RepSox in HOS and 143B cells at $96 \mathrm{~h}$ were 140 and $149.3 \mu \mathrm{M}$, respectively. (C and D) HOS and 143B cells were induced by different concentrations of RepSox for 14 days and then stained with crystal violet dye. Scale bars, $500 \mu \mathrm{m}$. (E and F) The proliferation ability of HOS and 143B cells was evaluated by soft agar colony formation assay, and the number of colonies was counted. Scale bars, $100 \mu \mathrm{m}$. (G and H) HOS and 143B cells were exposed to different concentrations of RepSox for $48 \mathrm{~h}$, and then cell cycle assays were performed by flow cytometry, and the cell cycle distribution after RepSox treatment was analyzed. Data are presented as the mean \pm standard deviation from three independent experiments. ${ }^{*} \mathrm{P}<0.05,{ }^{* *} \mathrm{P}<0.01$ and ${ }^{* * *} \mathrm{P}<0.001$ vs. the control. $\mathrm{IC}_{50}$, half maximal inhibitory concentration. 
A
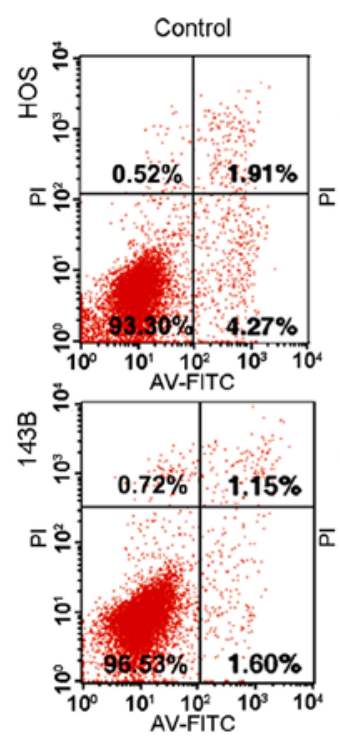

C

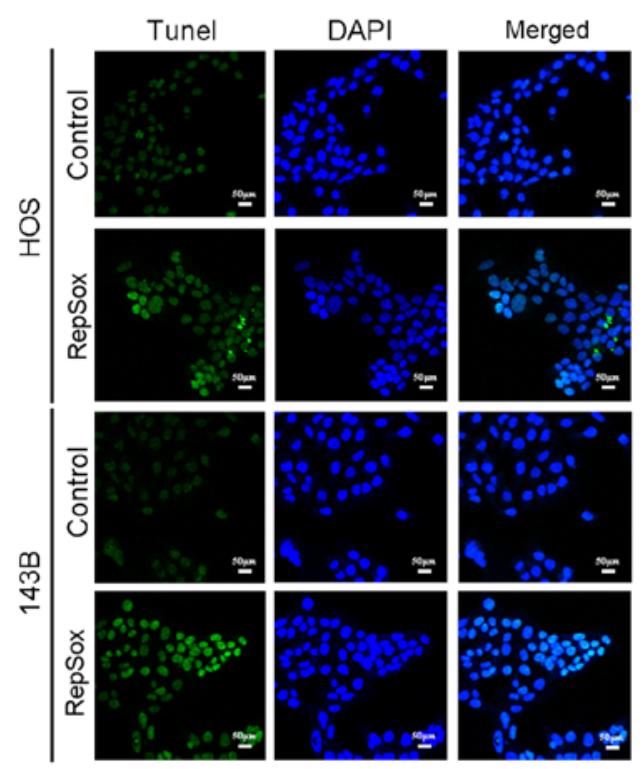

D

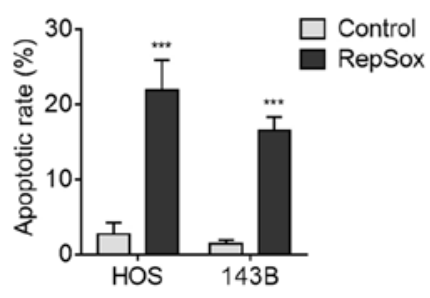

B
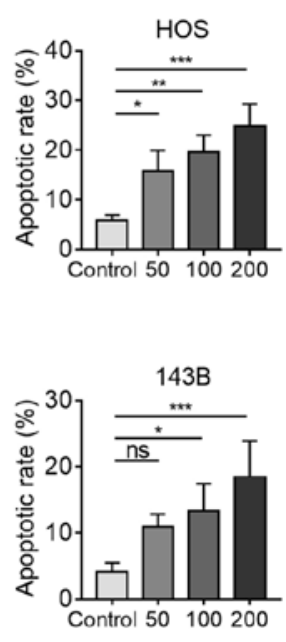

E

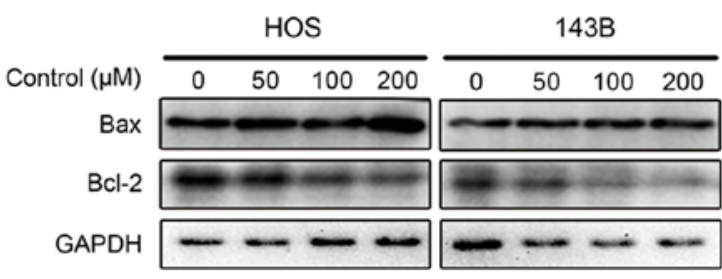

$\mathrm{F}$
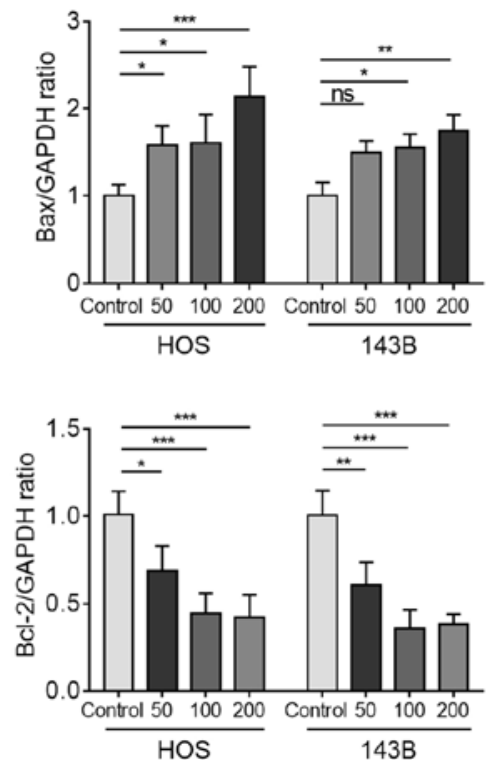

Figure 2. RepSox promotes osteosarcoma cell apoptosis. (A) HOS and 143B cells were treated with different concentrations of RepSox for 48 h, detected with an Annexin V-FITC/PI cell apoptosis kit, and finally analyzed by flow cytometry. (B) The proportion of apoptotic cells was quantified. (C) HOS and 143B cells were treated with $200 \mu \mathrm{M}$ RepSox, apoptotic cells exhibited green fluorescence, and nuclei were stained with DAPI (blue). Scale bars, $50 \mu \mathrm{m}$. (D) The TUNEL-positive cells were quantified. (E) After exposure to different concentrations of RepSox, apoptosis-related proteins in HOS and 143B cells were assessed by western blotting. (F) The densitometric levels of Bax and Bcl-2 were quantified and normalized to that of GAPDH. Data are presented as the mean \pm standard deviation from three independent experiments. ${ }^{*} \mathrm{P}<0.05,{ }^{* *} \mathrm{P}<0.01$ and ${ }^{* * *} \mathrm{P}<0.001 \mathrm{vs}$. the control. FITC/PI, fluorescein isothiocyanate/ propidine iodide; DAPI, 4',6-diamidino-2-phenylindole; TUNEL, terminal-deoxynucleotidyl-transferase-mediated dUTP nick end labeling; GAPDH, glyceraldehyde-3-phosphate dehydrogenase.

RepSox exerts anti-OS effects via the JNK/Smad3 pathway. Previous studies indicated that MAPK and Smad signaling pathways have great importance for tumor progression (20-25).
Firstly, analysis of gene expression revealed that treatment with $200 \mu \mathrm{M}$ RepSox significantly inhibited the expression of TGF- $\beta$ mRNA (Fig. 4A). Next, it was verified whether 
A

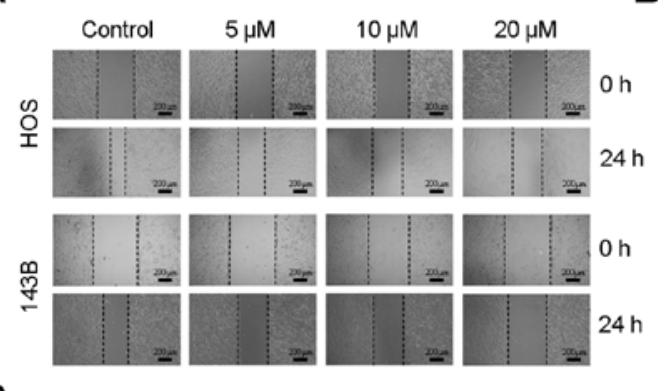

B

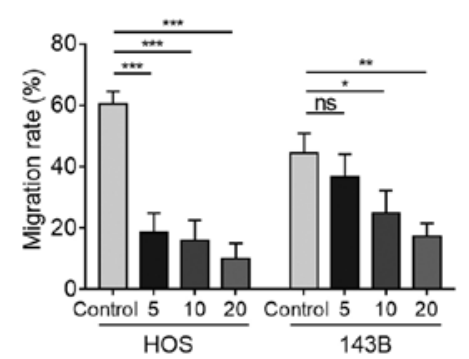

C
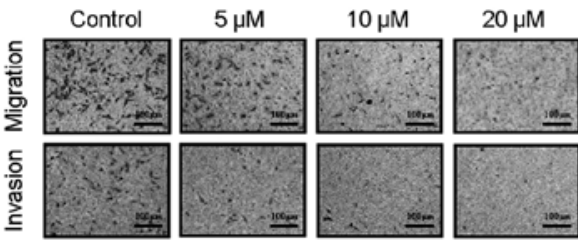

HOS

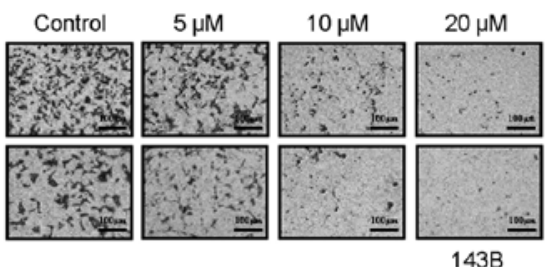

D

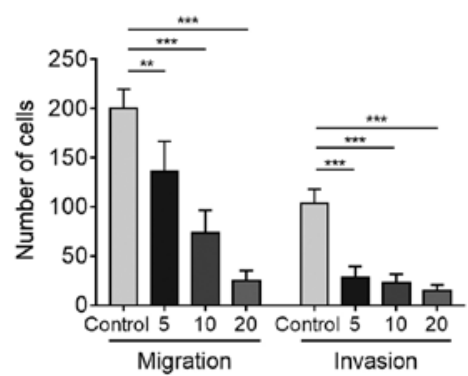

E

MMP-2 MMP-9

F
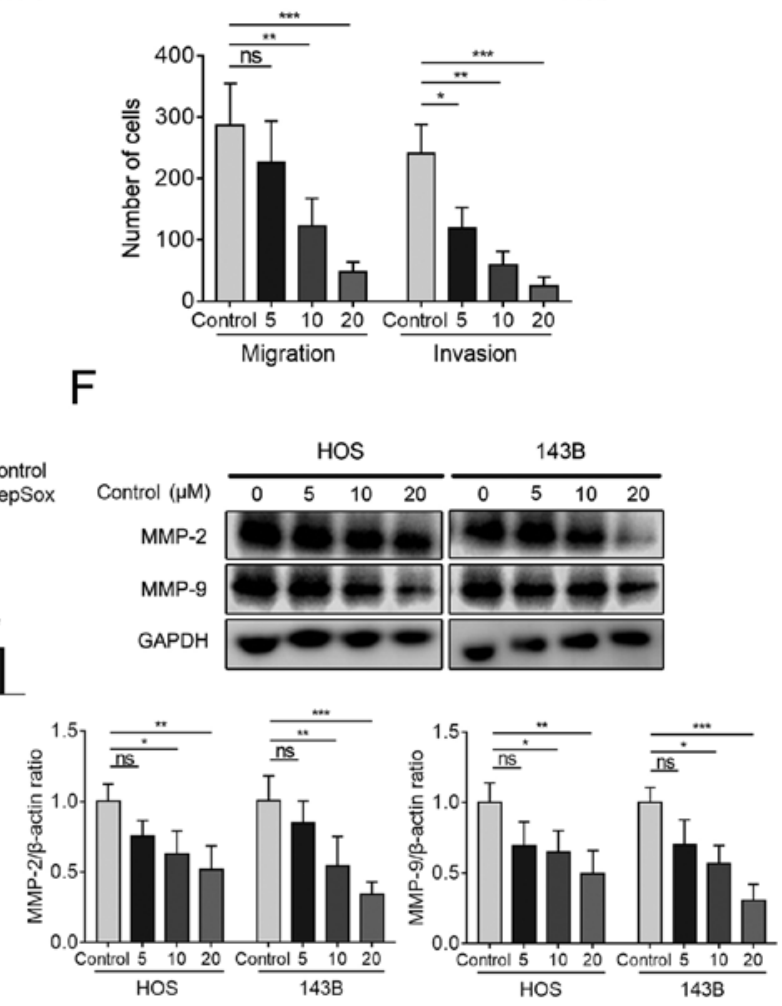

$\mathrm{H}$

G
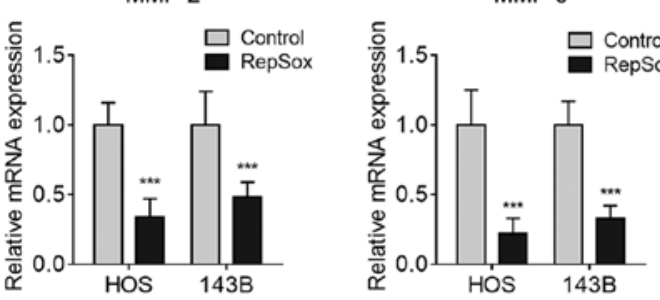

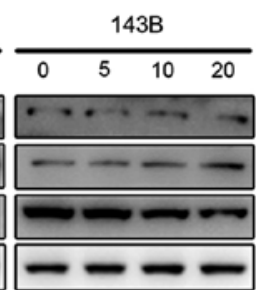

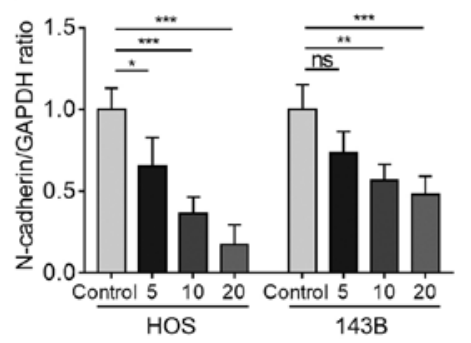
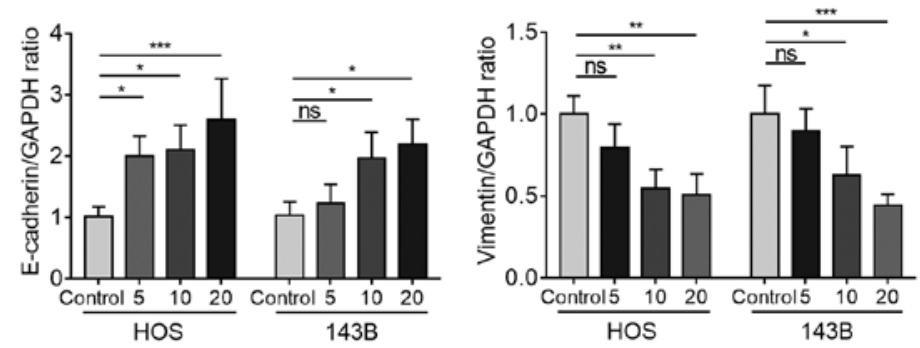

Figure 3. RepSox inhibits migration in OS cells. (A) When the HOS and 143B cells in 6-well plates were confluent, $200 \mu 1$ pipette tips were used to scratch wounds, after which the medium was replaced with different concentrations of RepSox prepared in serum-free medium, and the cells were cultured for $24 \mathrm{~h}$. Scale bars, $200 \mu \mathrm{m}$. (B) The migration ability was quantified. (C) Cells induced by different concentrations of RepSox were seeded into Transwell chambers for the cell migration assay for $24 \mathrm{~h}$. In contrast to the cell migration assay, the cell invasion assay used Matrigel-coated Transwell chambers for $24 \mathrm{~h}$. Scale bars, $100 \mu \mathrm{m}$. (D) Cells that migrated and invaded were counted. (E) Reverse transcription-quantitative PCR was used to detect the gene expression levels of MMP-2 and MMP-9 in HOS and 143B cells after RepSox induction for $24 \mathrm{~h}$. (F) Western blotting was used to detect the protein expression levels of MMP-2 and MMP-9 in HOS and 143B cells after RepSox induction for $24 \mathrm{~h}$. The densitometric levels of MMP-2 and MMP-9 were quantified and normalized to GAPDH. (G) Western blotting was conducted to assess the expression of EMT-related proteins. (H) The protein bands of EMT-related proteins were quantified and normalized to GAPDH. Data are presented as the mean \pm standard deviation from three independent experiments. ${ }^{*} \mathrm{P}<0.05$, ${ }^{* *} \mathrm{P}<0.01$ and ${ }^{* * *} \mathrm{P}<0.001 \mathrm{vs}$. the control. MMP, matrix metalloproteinase; EMT, epithelial-mesenchymal transition; ns, not significance. 
A

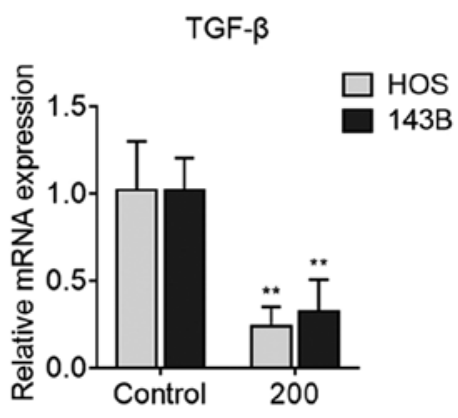

B

C
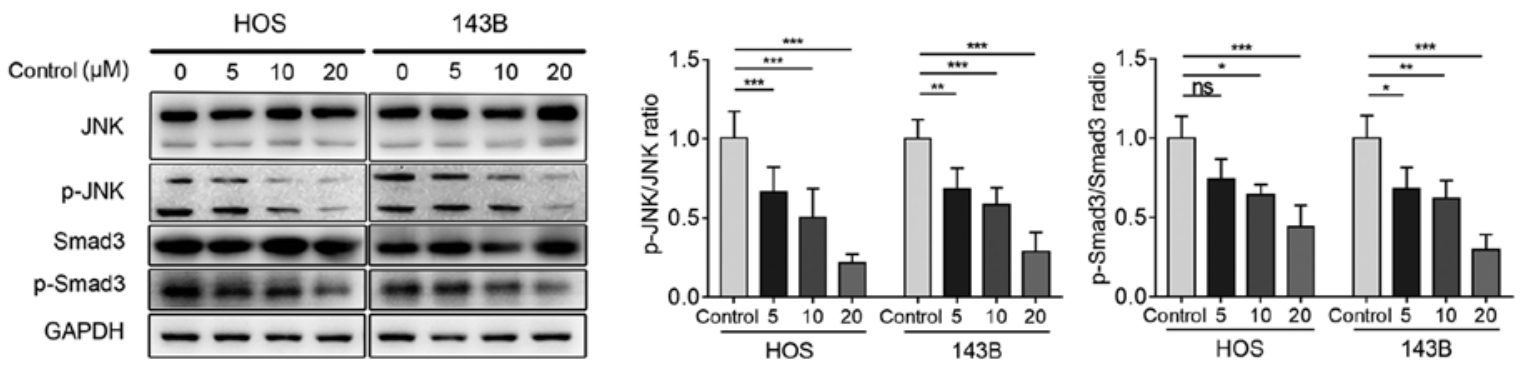

D

E
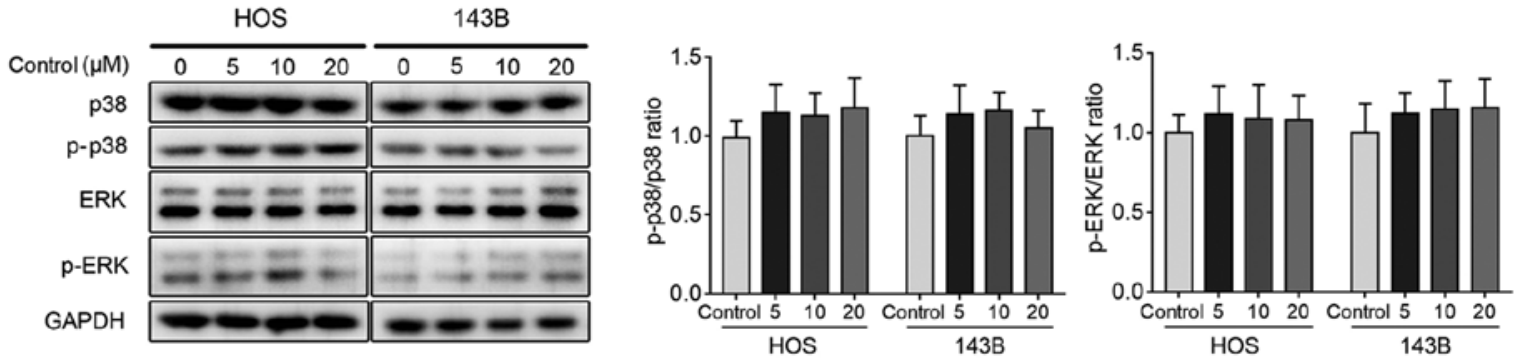

Figure 4. RepSox exerts an anti-osteosarcoma effect via the JNK/Smad3 pathway. (A) Reverse transcription-quantitative PCR was used to detect the gene expression level of transforming growth factor- $\beta$ in HOS and 143B cells after RepSox induction for $24 \mathrm{~h}$. (B) After treatment with RepSox at different concentrations, western blotting was performed to compare the expression levels of JNK, p-JNK, Smad3 and p-Smad3 proteins. (C) Western blot analysis revealed the p-JNK and p-Smad3 protein levels and then normalized them to total JNK and Smad3. (D) HOS and 143B cells were treated as indicated in B, and western blotting was performed to compare the expression levels of p38, p-p38, ERK and p-ERK proteins. (E) Western blot analysis revealed the p-p38 and p-ERK protein levels and then normalized to total $\mathrm{p} 38$ and ERK. Data are presented as the mean \pm standard deviation from three independent experiments. ${ }^{*} \mathrm{P}<0.05$, ${ }^{* * *} \mathrm{P}<0.01$ and ${ }^{* * * *} \mathrm{P}<0.001$ vs. the control. JNK, c-Jun amino-terminal kinase; TGF- $\beta$, transforming growth factor- $\beta$; p-, phosphorylated; ERK, extracellular signal-regulated kinase; ns, no significance.

MAPKs and Smad play a crucial role in the inhibitory effects of RepSox in OS cells. The results revealed that the phosphorylation of JNK and Smad3 was significantly inhibited after RepSox treatment (Fig. 4B and C), while the phosphorylation of p38 and ERK was not significantly altered (Fig. 4D and E). All this data indicated that RepSox exerted an anti-OS effect via the JNK/Smad3 pathway.

RepSox inhibits OS growth in vivo. To clarify the anticancer effect of RepSox in vivo, a xenograft model was established and randomly divided into three groups, receiving intraperitoneal administration of RepSox $(5 \mathrm{mg} / \mathrm{kg}$ or $20 \mathrm{mg} / \mathrm{kg}$ every other day) or DMSO. In terms of drug concentration selection for the in vivo experiment, on the one hand, the CCK- 8 data of our in vitro experiment were considered, and on the other hand, some published literature (26-28) on drug concentrations of other drugs in OS xenograft models was consulted. After three weeks, the tumors were removed from each nude mouse and measured (Fig. 5A and B). The RepSox-treated group exhibited a significant decrease in both tumor volume and weight (Fig. 5C and D). However, there was no significant difference in body weight between the control group and RepSox-treated groups (Fig. 5E). The results of immunohistochemistry revealed an obvious decrease in Bcl-2, N-cadherin, vimentin, MMP-2 and MMP-9 expression, along with a reduction in the proliferation marker Ki67. Conversely, the expression of E-cadherin and Bax was upregulated (Fig. 5F). A TUNEL assay was utilized to confirm the proapoptotic effect of RepSox on tumors in vivo. It was revealed that as the RepSox concentration increased, TUNEL-positive cells also increased in tumor tissue compared with the control group (Fig. 5G and H). The hearts, livers, spleens, lungs and kidneys of the mice were removed for further histological observation. H\&E-stained sections revealed intact tissue structure in all three groups, no OS metastatic lesions and no cytotoxic effects (Fig. 5I). In conclusion, these results revealed that RepSox efficiently suppressed the growth of OS and had low toxicity in nude mice. 
A

B
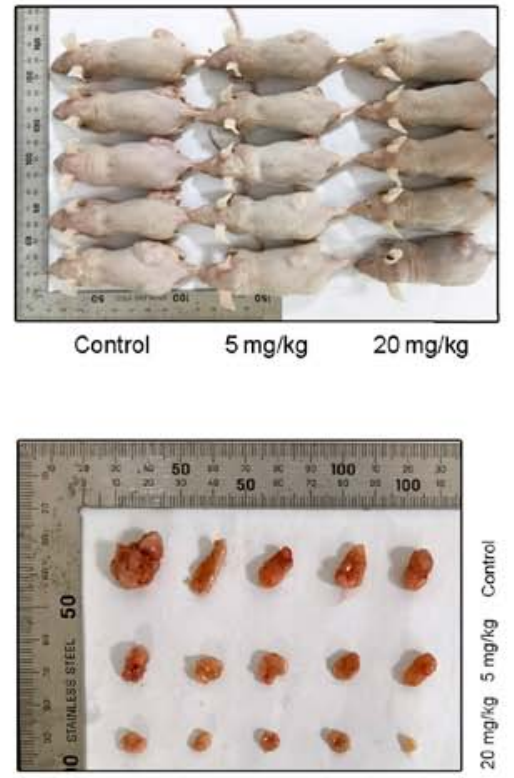

C

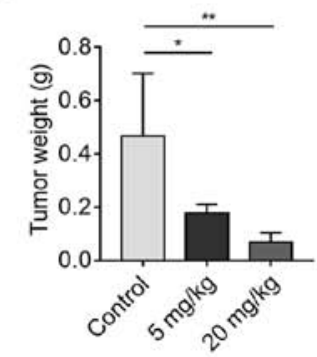

D

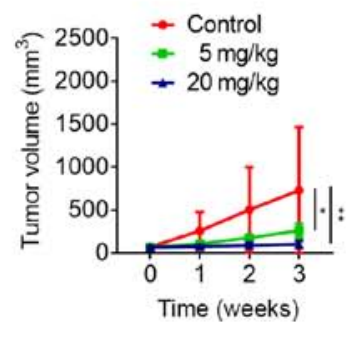

E

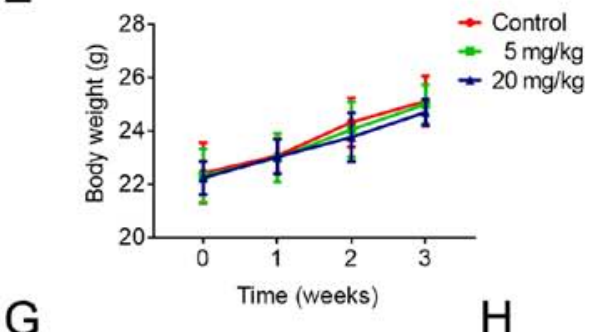

G

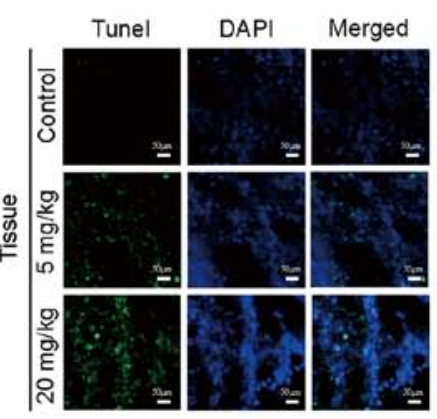

F
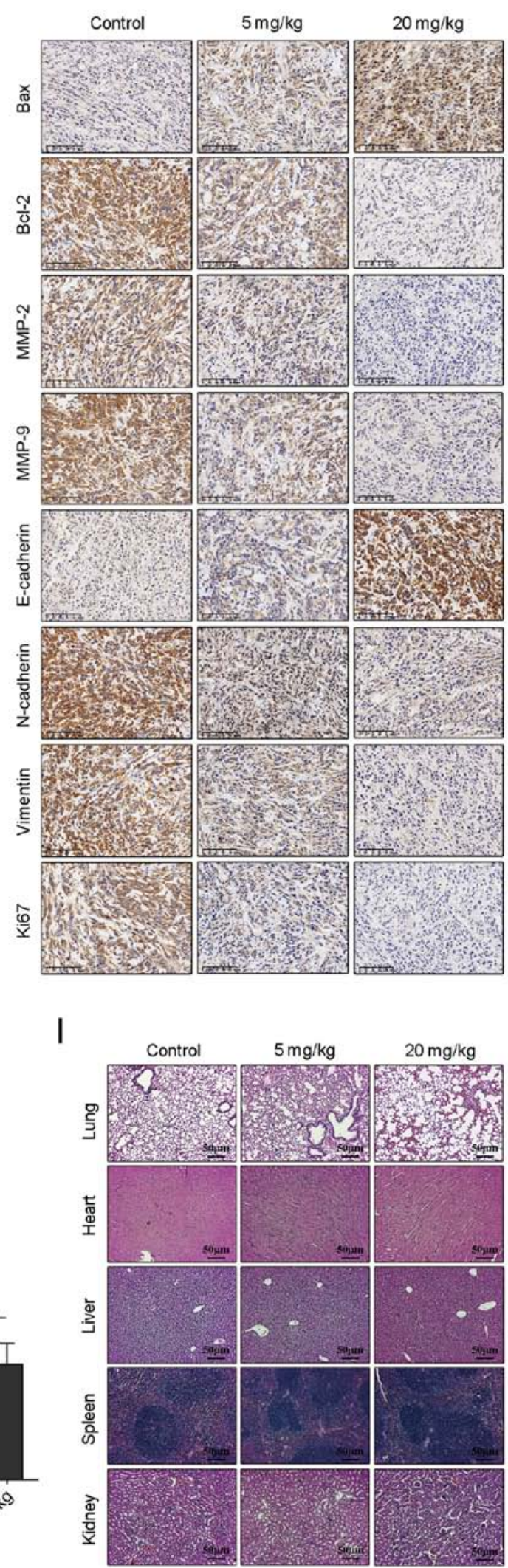

Figure 5. RepSox inhibits osteosarcoma growth in vivo. A xenograft model in 6-week-old male nude mice was established by subcutaneous injection of 143B cells on both sides of the back. After one week of modeling, mice randomly divided into three groups began to receive intraperitoneal administration of RepSox (5 mg/kg or $20 \mathrm{mg} / \mathrm{kg}$ every other day) or DMSO (control group). (A) Tumors in vivo are presented. (B) Tumors were removed from the nude mice. (C) The tumors were weighed and analyzed. (D and E) The tumor volume and body weight of mice were measured weekly. (F) Representative images of Bax, Bcl-2, MMP-2, MMP-9, E-cadherin, N-cadherin, vimentin and Ki67 immunostaining obtained by a light microscope. Scale bars, $50 \mu \mathrm{m}$. (G) Tumor tissue from the three groups was stained with a TUNEL kit. Scale bars, $50 \mu \mathrm{m}$. (H) TUNEL-positive tissue was quantified. (I) Hematoxylin and eosin staining of major organs is presented. Scale bars, $50 \mu \mathrm{m}$. Data are presented as the mean \pm standard deviation from three independent experiments. ${ }^{*} \mathrm{P}<0.05$, ${ }^{* *} \mathrm{P}<0.01$ and ${ }^{* * *} \mathrm{P}<0.001$ vs. the control. MMP, matrix metalloproteinase; TUNEL, terminal-deoxynucleotidyl-transferase-mediated dUTP nick end labeling; DAPI, 4',6-diamidino-2-phenylindole. 


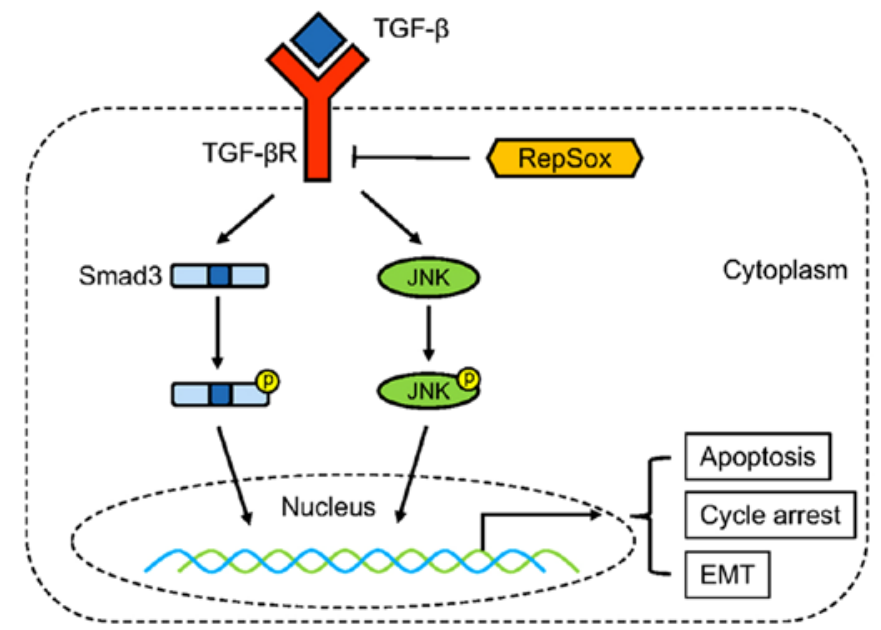

Figure 6. Schematic representation of how RepSox induces cell cycle arrest and apoptosis and inhibits epithelial-mesenchymal transition in osteosarcoma cells. EMT, epithelial-mesenchymal transition; TGF- $\beta$, transforming growth factor- $\beta$.

\section{Discussion}

OS is a malignant primary bone tumor that mainly occurs in children and adolescents (1). Its prognosis is poor, especially in patients with metastases at diagnosis and patients who are resistant to chemotherapy $(29,30)$. In this context, it is urgent to study the mechanism of OS development and find new targets for OS treatment. Previous studies revealed that TGF- $\beta$ plays an important role in tumor progression and can promote the metastasis of numerous solid tumors, such as breast, colon and prostate cancer $(8,31-33)$. Interestingly, TGF- $\beta$ exhibits dual effects on tumor progression, which is, inhibiting tumor progression in premalignant tumors and promoting tumor development in advanced tumors (34-36). However, some studies have indicated that compared with its role in malignant epithelial neoplasms, TGF- $\beta$ in sarcoma mainly exerts a tumor-promoting effect, especially in OS $(12,37)$. In patients with OS, the expression of TGF- $\beta 1$ and TGF- $\beta 2$ in serum is significantly higher than that in healthy donors $(11,12)$. Previous studies have reported that high levels of TGF- $\beta 1$ mRNA expression in tumor cells were associated with high-grade OS and frequent metastasis to the lung or other organs $(38,39)$. According to the literature, SD-208, a TGF- $\beta$ RI inhibitor, can significantly reduce the incidence of lung metastasis in OS, which is similar to the results of our study (12). The present study explored the inhibitory effect of RepSox on OS cells. In brief, RepSox inhibited the proliferation and metastasis of OS cells and induced apoptosis in vitro through the JNK/Smad3 signaling pathway, and its inhibitory effect on tumors was also confirmed in vivo.

In our experiments, a small molecule TGF- $\beta$ RI/ALK5 inhibitor (RepSox) was selected to evaluate its effect on OS cells. It was revealed that RepSox significantly inhibited the proliferation of OS cells in vitro. Mechanistically, it was revealed that this result was mainly caused by cell cycle arrest and increased apoptosis. Therefore, a literature search was conducted and it was revealed that TGF- $\beta$ can increase the expression of CDK inhibitors $1 \mathrm{~A}$ (CDKN1A or p21), 2B (CDKN2B or p15) and $1 \mathrm{C}(\mathrm{CNKN1C}$ or p57) and apoptosis inducer death-associated protein kinase (DAPK) (40-42), thereby inducing cell cycle arrest and promoting apoptosis. Cell cycle arrest is recognized as an important cause of proliferation inhibition. This process is closely monitored by some checkpoints and will be induced to pause when necessary $(43,44)$. Cyclins and CDKs are key regulators of the cell cycle (45). CDK2 is activated by binding to cyclin $\mathrm{E}$, while cyclin $\mathrm{E}$, in complex with $\mathrm{CDK} 2$, drives the transition from the late $\mathrm{G} 1$ phase to the $\mathrm{S}$ phase (46). In addition, the association of CDK2 and cyclin A are also essential for G1/S progression (47). Concurrently, as an important protein inhibitor in the cell cycle, p21 can also bind to CDK, resulting in a block in cell cycle progression (48). In the present study, RepSox promoted the transition of cells to the $S$ phase by upregulating cyclin E1 and p21, and reduced cyclin A2 and CDK2 to arrest the cell cycle in the $\mathrm{S}$ phase. In addition, c-Myc, another key transcriptional activator of cell proliferation, has been revealed to be inhibited (49).

As aforementioned, TGF- $\beta$ plays the role of a tumor suppressor, which is exactly the opposite of our experimental results. A possible explanation is that cancer cells bypass these cytostatic effects by inactivating key molecules in the TGF- $\beta$ signaling pathway and crosstalk with other oncogenic pathways (49). Malignant tumor cells may retain the TGF- $\beta /$ Smad pathway, but they can promote tumor progression by acquiring noncanonical PI3K/AKT, RAS/MAPK, or p53 pathway carcinogenic mutations (50). In our research, it was revealed that the JNK/Smad3 signaling pathway was inhibited (Fig. 6), which may explain the aforementioned phenomenon, but the specific mechanism still requires further study.

In the subsequent wound-healing, cell migration and invasion assays, the drug concentration was changed in order to exclude the biased results caused by cell proliferation. The results revealed that RepSox could also significantly inhibit the migration and invasion of tumor cells below the cytotoxic concentration, which fully indicated that RepSox had a quite evident inhibitory effect on the metastasis of OS cells.

As aforementioned, TGF- $\beta$ has a dual effect in tumors, and ultimately, the function of TGF- $\beta$ is related to its ability to induce epithelial-mesenchymal transition (EMT) programs (51). Sarcoma has a mesenchymal origin, and its mesenchymal phenotype is maintained by the functions of EMT transcription factors (EMT-TFs), including TWIST1, NAIL, SLUG, ZEB1 and ZEB2, and associated with more aggressive behaviors (52). A number of studies indicated that overexpression of EMT-related transcription factors is implicated in the OS pathogenesis, which may be a significant reason for EMT (53-56). In addition, several in vitro studies have confirmed that the ability of TGF- $\beta$ s to promote EMT programs in various OS cell lines may be linked to the promigratory effect of TGF- $\beta$ I (57-60). In addition, Smad and MAP-kinase signaling are essential for the transcriptional induction of numerous extracellular matrix (ECM) proteins, such as MMPs (e.g., MMP-2 and MMP-9) $(61,62)$. Multiple previous studies (63-66) demonstrated that inhibition of the phosphorylation of JNK can reduce the expression of MMP-2/MMP-9 in OS cells. Furthermore, a study by Lamora et al (67) revealed that halofuginone decreased the expression and activity of MMP-2 by inhibiting the 
TGF- $\beta /$ Smad 3 cascade in OS. In our study, RepSox inhibited the expression of MMP-2 and MMP-9 in a concentration-dependent manner, reducing transcription-induced stimulation of ECM-related proteins. In parallel, hallmarks of mesenchymal phenotypes include the expression of vimentin-based intermediate filaments, the exchange of E-cadherin-based with N-cadherin-based junctions, and the extensive synthesis of ECM proteins and matrix remodeling enzymes (metalloproteases) that facilitate the migration and invasiveness of mesenchymal and inflammatory cells (68). Our data revealed that the expression of E-cadherin was increased under the effect of RepSox, while the expression of $\mathrm{N}$-cadherin and vimentin was inhibited, indicating that RepSox enhanced the adhesion between tumor cells and reduced the migration and invasion of tumor cells.

In in vivo experiments, several tumor xenograft models in literature have been used, and it was revealed that they all adopted the 143B cell line as the source of tumor cells. In addition, in our in vitro experiments, it was observed that $143 \mathrm{~B}$ cells proliferated faster than HOS cells. It was hypothesized that this may render the experimental results more intuitive, therefore the 143B cell line was selected. Meanwhile, in addition to the 143B cell line, other OS cell lines should also be used for in vivo xenograft studies. However, due to constraints on research funds and time, only the 143B cell line was selected for in vivo experiments in the present study, which is also a limitation of the present study.

With regard to the tumors in the in vivo experiments that appear to have a more pronounced inhibitory effect than in the in vitro experiments, it was hypothesized that this may be due to the effect of migration inhibitory factor (MIF) on the tumor microenvironment. Several studies have revealed that treatment with anti-MIF antibodies significantly inhibited the growth of murine colon cancer, and concurrently suppressed its angiogenesis $(69,70)$. Moreover, a series of in vitro and in vivo experimental results indicated that MIF deficiency attenuated tumor-polarized macrophage alternative activation, immunosuppression, neoangiogenesis, and melanoma tumor outgrowth (71). The aforementioned results revealed the effect of MIF and its inhibitors on the tumor microenvironment and that is also our future direction of the present study. In addition, in vivo pharmacokinetic and bioavailability studies on RepSox are required.

In addition, in recent years, nanomedicine is rapidly advancing as an emerging field. Nanomaterials are gradually used as an effective carrier for the diagnosis and treatment of diseases (72-76). In the chemotherapy of OS, conventional small-molecule therapeutics exhibit low efficacies and severe side effects, while the drug-delivery platforms based on nanotechnology can significantly improve the antitumor efficacy and diminish the side effects (74). It has broad application prospects in OS chemotherapy. In addition, the development and innovation of biocomposites also provide novel insights for the treatment of OS (77).

In summary, our study revealed that RepSox could induce cycle arrest and apoptosis of OS cells and inhibit EMT by inhibiting the JNK/Smad3 pathway, which was also further demonstrated in in vivo experiments. Therefore, RepSox may be potentially valuable as an alternate therapeutic agent for OS treatment.

\section{Acknowledgements}

Not applicable.

\section{Funding}

The present study was supported by the Zhejiang Province Medical Science and Technology Project (grant no. 2021425397), the Zhejiang Province Scientific Project of Health and Medicine of China (grant no. 2018KY936) and the Public Welfare Technology Application Research Project of Lishui City (grant no. 2020GYX21).

\section{Availability of data and materials}

The datasets generated and/or analyzed during the current study are available from the corresponding author on reasonable request.

\section{Authors' contributions}

DH and SF conceived and designed the experiments. DH, JG, LZ, SL, LY and HL performed the experiments. DH, BP, WP and ZC conducted the statistical analyses. CL helped to perform the analyses with constructive suggestions. DH wrote the paper and SF revised the paper. DH and JG confirm the authenticity of all the raw data. All authors read and approved the final manuscript.

\section{Ethics approval and consent to participate}

The animal experiments were approved by the Animal Care Ethics Committee of Sir Run Run Shaw Hospital (Hangzhou, China).

\section{Patient consent for publication}

Not applicable.

\section{Competing interests}

The authors declare that they have no competing interests.

\section{References}

1. Friedrich P, Ortiz R, Strait K, Fuentes S, Gamboa Y, Arambú I, Ah-Chu-Sanchez M, London W, Rodríguez-Galindo C, Antillón-Klussmann F, et al; Central American Association of Pediatric Hematologists Oncologists AHOPCA: Pediatric sarcoma in Central America: Outcomes, challenges, and plans for improvement. Cancer 119: 871-879, 2013

2. Ottaviani G and Jaffe N: The epidemiology of osteosarcoma. Cancer Treat Res 152: 3-13, 2009.

3. Bacci G, Longhi A, Versari M, Mercuri M, Briccoli A and Picci P: Prognostic factors for osteosarcoma of the extremity treated with neoadjuvant chemotherapy: 15-year experience in 789 patients treated at a single institution. Cancer 106: 1154-1161, 2006.

4. Bielack SS, Kempf-Bielack B, Delling G, Exner GU, Flege S, Helmke K, Kotz R, Salzer-Kuntschik M, Werner M, Winkelmann W, et al: Prognostic factors in high-grade osteosarcoma of the extremities or trunk: An analysis of 1,702 patients treated on neoadjuvant cooperative osteosarcoma study group protocols. J Clin Oncol 20: 776-790, 2002. 
5. Derynck R and Zhang YE: Smad-dependent and Smad-independent pathways in TGF-beta family signalling. Nature 425: 577-584, 2003.

6. Zhang YE: Non-Smad signaling pathways of the TGF- $\beta$ family. Cold Spring Harb Perspect Biol 9: 9, 2017.

7. Batlle E and Massagué J: Transforming growth factor- $\beta$ signaling in immunity and cancer. Immunity 50: 924-940, 2019.

8. Walker RA and Dearing SJ: Transforming growth factor beta 1 in ductal carcinoma in situ and invasive carcinomas of the breast. Eur J Cancer 28: 641-644, 1992.

9. Adekoya TO and Richardson RM: Cytokines and chemokines as mediators of prostate cancer metastasis. Int J Mol Sci 21: 21, 2020.

10. Stolfi C, Troncone E, Marafini I and Monteleone G: Role of TGF-beta and Smad7 in gut inflammation, fibrosis and cancer. Biomolecules 11: 11, 2020.

11. Xu S, Yang S, Sun G, Huang W and Zhang Y: Transforming growth factor-beta polymorphisms and serum level in the development of osteosarcoma. DNA Cell Biol 33: 802-806, 2014.

12. Lamora A, Talbot J, Bougras G, Amiaud J, Leduc M, Chesneau J, Taurelle J, Stresing V, Le Deley MC, Heymann MF, et al: Overexpression of smad7 blocks primary tumor growth and lung metastasis development in osteosarcoma. Clin Cancer Res 20 5097-5112, 2014.

13. Gellibert F, Woolven J, Fouchet MH, Mathews N, Goodland H, Lovegrove V, Laroze A, Nguyen VL, Sautet S, Wang R, et al: Identification of 1,5-naphthyridine derivatives as a novel series of potent and selective TGF-beta type I receptor inhibitors. J Med Chem 47: 4494-4506, 2004.

14. Ichida JK, Blanchard J,Lam K, Son EY, Chung JE, Egli D, Loh KM Carter AC, Di Giorgio FP, Koszka K, et al: A small-molecule inhibitor of tgf-Beta signaling replaces sox 2 in reprogramming by inducing nanog. Cell Stem Cell 5: 491-503, 2009.

15. Mei L, Sang W, Chen Z,Zheng L, Jin K, Lou C, Huang W and He D Small molecule inhibitor RepSox prevented ovariectomy-induced osteoporosis by suppressing osteoclast differentiation and bone resorption. J Cell Physiol 233: 9724-9738, 2018.

16. Fu Y, Huang C, Xu X, Gu H, Ye Y, Jiang C, Qiu Z and Xie X: Direct reprogramming of mouse fibroblasts into cardiomyocytes with chemical cocktails. Cell Res 25: 1013-1024, 2015.

17. Jajosky AN, Coad JE, Vos JA, Martin KH, Senft JR, Wenger SL and Gibson LF: RepSox slows decay of CD34+ acute myeloid leukemia cells and decreases T cell immunoglobulin mucin-3 expression. Stem Cells Transl Med 3: 836-848, 2014.

18. Ide M, Jinnin M, Tomizawa Y, Wang Z, Kajihara I, Fukushima S, Hashizume Y, Asano Y and Ihn H: Transforming growth factor $\beta$-inhibitor Repsox downregulates collagen expression of scleroderma dermal fibroblasts and prevents bleomycin-induced mice skin fibrosis. Exp Dermatol 26: 1139-1143, 2017.

19. Livak KJ and Schmittgen TD: Analysis of relative gene expression data using real-time quantitative PCR and the 2(-Delta Delta C(T)) method. Methods 25: 402-408, 2001.

20. Jiang X, Shan J, Dai N, Zhong Z, Qing Y, Yang Y, Zhang S, Li C, Sui J, Ren T, et al: Apurinic/apyrimidinic endonuclease 1 regulates angiogenesis in a transforming growth factor $\beta$-dependent manner in human osteosarcoma. Cancer Sci 106: 1394-1401, 2015

21. Lu KH, Su SC, Lin CW, Hsieh YH, Lin YC, Chien MH, Reiter RJ and Yang SF: Melatonin attenuates osteosarcoma cell invasion by suppression of $\mathrm{C}-\mathrm{C}$ motif chemokine ligand 24 through inhibition of the c-Jun N-terminal kinase pathway. J Pineal Res 65 : e12507, 2018

22. Sun Y, Xia P, Zhang H, Liu B and Shi Y: P53 is required for Doxorubicin-induced apoptosis via the TGF-beta signaling pathway in osteosarcoma-derived cells. Am J Cancer Res 6 : $114-125,2015$

23. Wang H, Zhang T, Sun W, Wang Z, Zuo D, Zhou Z, Li S, $\mathrm{Xu}$ J, Yin F, Hua Y, et al: Erianin induces G2/M-phase arrest, apoptosis, and autophagy via the ROS/JNK signaling pathway in human osteosarcoma cells in vitro and in vivo. Cell Death Dis $7:$ e2247, 2016.

24. Wang S, Li H, Chen S, Wang Z, Yao Y, Chen T, Ye Z and Lin P: Andrographolide induces apoptosis in human osteosarcoma cells via the ROS/JNK pathway. Int J Oncol 56: 1417-1428, 2020.

25. Wang Y, Deng X, Yu C, Zhao G, Zhou J, Zhang G, Li M, Jiang D, Quan Z and Zhang Y: Synergistic inhibitory effects of capsaicin combined with cisplatin on human osteosarcoma in culture and in xenografts. J Exp Clin Cancer Res 37: 251, 2018.

26. Jie Z, Xie Z, Zhao X, Sun X, Yu H, Pan X, Shen S, Qin A, Fang X and Fan S: Glabridin inhibits osteosarcoma migration and invasion via blocking the p38- and JNK-mediated CREB-AP1 complexes formation. J Cell Physiol 234: 4167-4178, 2019.
27. Lin RC, Yang SF, Chiou HL, Hsieh SC, Wen SH, Lu KH and Hsieh YH: Licochalcone A-induced apoptosis through the activation of p38MAPK pathway mediated mitochondrial pathways of apoptosis in human osteosarcoma cells in vitro and in vivo. Cells 8: 8, 2019.

28. Lu KH, Chen PN, Hsieh YH, Lin CY, Cheng FY, Chiu PC, Chu SC and Hsieh YS: 3-Hydroxyflavone inhibits human osteosarcoma U2OS and 143B cells metastasis by affecting EMT and repressing u-PA/MMP-2 via FAK-Src to MEK/ERK and RhoA/MLC2 pathways and reduces 143B tumor growth in vivo. Food Chem Toxicol 97: 177-186, 2016.

29. Goorin AM, Harris MB, Bernstein M, Ferguson W, Devidas M, Siegal GP, Gebhardt MC, Schwartz CL, Link M and Grier HE: Phase II/III trial of etoposide and high-dose ifosfamide in newly diagnosed metastatic osteosarcoma: A pediatric oncology group trial. J Clin Oncol 20: 426-433, 2002.

30. Kempf-Bielack B, Bielack SS, Jürgens H, BranscheidD, Berdel WE, Exner GU, Göbel U, Helmke K, Jundt G, Kabisch H, et al: Osteosarcoma relapse after combined modality therapy: An analysis of unselected patients in the Cooperative Osteosarcoma Study Group (COSS). J Clin Oncol 23: 559-568, 2005.

31. Bierie B and Moses HL: Tumour microenvironment: TGFbeta: the molecular Jekyll and Hyde of cancer. Nat Rev Cancer 6: 506-520, 2006.

32. Friedman E, Gold LI, Klimstra D, Zeng ZS, Winawer S and Cohen A: High levels of transforming growth factor beta 1 correlate with disease progression in human colon cancer. Cancer Epidemiol Biomarkers Prev 4: 549-554, 1995.

33. Wikström P, Stattin P, Franck-Lissbrant I, Damber JE and Bergh A: Transforming growth factor betal is associated with angiogenesis, metastasis, and poor clinical outcome in prostate cancer. Prostate 37: 19-29, 1998.

34. Roberts $\mathrm{AB}$ and Wakefield LM: The two faces of transforming growth factor beta in carcinogenesis. Proc Natl Acad Sci USA 100: 8621-8623, 2003.

35. Derynck R, Akhurst RJ and Balmain A: TGF-beta signaling in tumor suppression and cancer progression. Nat Genet 29: $117-129,2001$.

36. Costanza B, Umelo IA, Bellier J, Castronovo V and Turtoi A Stromal modulators of TGF- $\beta$ in cancer. J Clin Med 6: 6, 2017.

37. Matsuyama S, Iwadate M, Kondo M, Saitoh M, Hanyu A, Shimizu K, Aburatani H, Mishima HK, Imamura T, Miyazono K, et al: SB-431542 and Gleevec inhibit transforming growth factor-beta-induced proliferation of human osteosarcoma cells. Cancer Res 63: 7791-7798, 2003.

38. Franchi A, Arganini L, Baroni G, Calzolari A, Capanna R, Campanacci D, Caldora P, Masi L, Brandi ML and Zampi G: Expression of transforming growth factor beta isoforms in osteosarcoma variants: Association of TGF beta 1 with high-grade osteosarcomas. J Pathol 185: 284-289, 1998.

39. Mohseny AB, Cai Y, Kuijjer M, Xiao W, van den Akker B, de Andrea CE, Jacobs R, ten Dijke P, Hogendoorn PC and Cleton-Jansen AM: The activities of Smad and Gli mediated signalling pathways in high-grade conventional osteosarcoma. Eur J Cancer 48: 3429-3438, 2012.

40. Jang CW, Chen CH, Chen CC, Chen JY, Su YH and Chen RH: TGF-beta induces apoptosis through Smad-mediated expression of DAP-kinase. Nat Cell Biol 4: 51-58, 2002.

41. Hannon GJ and Beach D: p15INK4B is a potential effector of TGF-beta-induced cell cycle arrest. Nature 371: 257-261, 1994.

42. Reynisdóttir I, Polyak K, Iavarone A and Massagué J: Kip/Cip and Ink4 Cdk inhibitors cooperate to induce cell cycle arrest in response to TGF-beta. Genes Dev 9: 1831-1845, 1995.

43. Ghelli Luserna di Rora' A, Iacobucci I and Martinelli G: The cell cycle checkpoint inhibitors in the treatment of leukemias. J Hematol Oncol 10: 77, 2017.

44. Wang JL, Quan Q, Ji R, Guo XY, Zhang JM, Li X and Liu YG: Isorhamnetin suppresses PANC-1 pancreatic cancer cell proliferation through S phase arrest. Biomed Pharmacother 108 925-933, 2018.

45. Szmyd R, Niska-Blakie J, Diril MK, Renck Nunes P, Tzelepis K, Lacroix A, van Hul N, Deng LW, Matos J, Dreesen O, et al: Premature activation of Cdk1 leads to mitotic events in $S$ phase and embryonic lethality. Oncogene 38: 998-1018, 2019.

46. Koff A, Giordano A, Desai D, Yamashita K, Harper JW, Elledge S, Nishimoto T, Morgan DO, Franza BR and Roberts JM: Formation and activation of a cyclin E-cdk 2 complex during the G1 phase of the human cell cycle. Science 257: 1689-1694, 1992.

47. Girard F, Strausfeld U, Fernandez A and Lamb NJ: Cyclin A is required for the onset of DNA replication in mammalian fibroblasts. Cell 67: 1169-1179, 1991. 
48. Xiong Y, Hannon GJ, Zhang H, Casso D, Kobayashi R and Beach D: p21 is a universal inhibitor of cyclin kinases. Nature 366: 701-704, 1993.

49. Yeh HW, Lee SS, Chang CY, Lang YD and Jou YS: A new switch for TGF $\beta$ in cancer. Cancer Res 79: 3797-3805, 2019.

50. Massagué J: TGFbeta in Cancer. Cell 134: 215-230, 2008.

51. Morrison CD, Parvani JG and Schiemann WP: The relevance of the TGF- $\beta$ Paradox to EMT-MET programs. Cancer Lett 341: 30-40, 2013.

52. Yu X, Yustein JT and Xu J: Research models and mesenchymal/ epithelial plasticity of osteosarcoma. Cell Biosci 11: 94, 2021.

53. Yang G, Yuan J and Li K: EMT transcription factors: Implication in osteosarcoma. Med Oncol 30: 697, 2013.

54. Sharili AS, Allen S, Smith K, Hargreaves J, Price J and McGonnell I: Expression of Snail2 in long bone osteosarcomas correlates with tumour malignancy. Tumour Biol 32: 515-526, 2011.

55. Wensman H, Göransson H, Leuchowius KJ, Strömberg S, Pontén F, Isaksson A, Rutteman GR, Heldin NE, Pejler G and Hellmén E: Extensive expression of craniofacial related homeobox genes in canine mammary sarcomas. Breast Cancer Res Treat 118: 333-343, 2009.

56. Wu J, Liao Q, He H, Zhong D and Yin K: TWIST interacts with $\beta$-catenin signaling on osteosarcoma cell survival against cisplatin. Mol Carcinog 53: 440-446, 2014.

57. Chen J, Song Y, Yang J, Gong L, Zhao P, Zhang Y and Su H: The up-regulation of cysteine-rich protein 61 induced by transforming growth factor beta enhances osteosarcoma cell migration. Mol Cell Biochem 384: 269-277, 2013.

58. Huang Y, Yang Y, Gao R, Yang X, Yan X, Wang C, Jiang S and Yu L: RLIM interacts with Smurf 2 and promotes TGF- $\beta$ induced U2OS cell migration. Biochem Biophys Res Commun 414 181-185, 2011.

59. Kunita A, Kashima TG, Ohazama A, Grigoriadis AE and Fukayama M: Podoplanin is regulated by AP-1 and promotes platelet aggregation and cell migration in osteosarcoma. Am J Pathol 179: 1041-1049, 2011.

60. Sung JY, Park SY, Kim JH, Kang HG, Yoon JH, Na YS, Kim YN and Park BK: Interferon consensus sequence-binding protein (ICSBP) promotes epithelial-to-mesenchymal transition (EMT)-like phenomena, cell-motility, and invasion via TGF- $\beta$ signaling in U2OS cells. Cell Death Dis 5: e1224, 2014.

61. Borok Z: Role for alpha3 integrin in EMT and pulmonary fibrosis. J Clin Invest 119: 7-10, 2009.

62. Javelaud D and Mauviel A: Crosstalk mechanisms between the mitogen-activated protein kinase pathways and Smad signaling downstream of TGF-beta: Implications for carcinogenesis. Oncogene 24: 5742-5750, 2005.

63. Chueh FS, Chen YY, Huang AC, Ho HC, Liao CL, Yang JS, Kuo CL and Chung JG: Bufalin-inhibited migration and invasion in human osteosarcoma U-2 OS cells is carried out by suppression of the matrix metalloproteinase-2, ERK, and JNK signaling pathways. Environ Toxicol 29: 21-29, 2014.

64. Fromigué O, Hamidouche $\mathrm{Z}$ and Marie PJ: Blockade of the RhoA-JNK-c-Jun-MMP2 cascade by atorvastatin reduces osteosarcoma cell invasion. J Biol Chem 283: 30549-30556, 2008.
65. Jung O and Lee SY: Synergistic anticancer effects of timosaponin AIII and ginsenosides in MG63 human osteosarcoma cells. J Ginseng Res 43: 488-495, 2019.

66. Liao CL, Lai KC, Huang AC, Yang JS, Lin JJ, Wu SH, Gibson Wood W, Lin JG and Chung JG: Gallic acid inhibits migration and invasion in human osteosarcoma U-2 OS cells through suppressing the matrix metalloproteinase-2/-9, protein kinase $\mathrm{B}$ (PKB) and PKC signaling pathways. Food Chem Toxicol 50: 1734-1740, 2012

67. Lamora A, Mullard M, Amiaud J, Brion R, Heymann D, Redini F and Verrecchia F: Anticancer activity of halofuginone in a preclinical model of osteosarcoma: Inhibition of tumor growth and lung metastases. Oncotarget 6: 14413-14427, 2015.

68. Thiery JP, Acloque H, Huang RY and Nieto MA: Epithelialmesenchymal transitions in development and disease. Cell 139 871-890, 2009

69. Nishihira J, Ishibashi T, Fukushima T, Sun B, Sato Y and Todo S: Macrophage migration inhibitory factor (MIF): Its potential role in tumor growth and tumor-associated angiogenesis. Ann NY Acad Sci 995: 171-182, 2003.

70. Ogawa H, Nishihira J, Sato Y, Kondo M, Takahashi N, Oshima T and Todo S: An antibody for macrophage migration inhibitory factor suppresses tumour growth and inhibits tumour-associated angiogenesis. Cytokine 12: 309-314, 2000.

71. Yaddanapudi K, Putty K, Rendon BE, Lamont GJ, Faughn JD, Satoskar A, Lasnik A, Eaton JW and Mitchell RA: Control of tumor-associated macrophage alternative activation by macrophage migration inhibitory factor. J Immunol 190: 2984-2993, 2013

72. Li Y, Li X, Lu Y, Chaurasiya B, Mi G, Shi D, Chen D, Webster TJ, $\mathrm{Tu} \mathrm{J}$ and Shen Y: Co-delivery of Poria cocos extract and doxorubicin as an 'all-in-one' nanocarrier to combat breast cancer multidrug resistance during chemotherapy. Nanomedicine 23: $102095,2020$.

73. Xu J, Wang H, Hu Y, Zhang YS, Wen L, Yin F, Wang Z, Zhang Y, Li S, Miao Y, et al: Inhibition of CaMKII $\alpha$ activity enhances antitumor effect of fullerene C60 nanocrystals by suppression of autophagic degradation. Adv Sci (Weinh) 6: 1801233, 2019.

74. Zhang Y, Wang F, Li M, Yu Z, Qi R, Ding J, Zhang Z and Chen X: Self-stabilized hyaluronate nanogel for intracellular codelivery of doxorubicin and cisplatin to osteosarcoma. Adv Sci (Weinh) 5: $1700821,2018$.

75. Li D, Xu W, Li P, Ding J, Cheng Z, Chen L, Yan L and Chen X: Self-targeted polysaccharide prodrug suppresses orthotopic hepatoma. Mol Pharm 13: 4231-4235, 2016.

76. Wang J, Li Z, Wang Z, Yu Y,Li D, Li B and Ding J: Nanomaterials for combinational radio-immuno oncotherapy. Adv Funct Mater 30: 1910676, 2020.

77. Zhao D, Zhu T, Li J, Cui L, Zhang Z, Zhuang X and Ding J: Poly(lactic-co-glycolic acid)-based composite bone-substitute materials. Bioact Mater 6: 346-360, 2020.

This work is licensed under a Creative Commons Attribution-NonCommercial-NoDerivatives 4.0 International (CC BY-NC-ND 4.0) License. 